\title{
Analisis Implementasi Kebijakan Work From Home pada Kesejahteraan Pengemudi Transportasi Online di Indonesia
}

\author{
Retnowati WD Tuti ${ }^{1 *}$ \\ ${ }^{1}$ Magister Ilmu Administrasi Fakultas Ilmu Sosial Dan Ilmu Politik Universitas Muhammadiyah Jakarta, Tangerang Selatan, 15419, Indonesia \\ ${ }^{1}$ retnowatiwdtuti@yahoo.com \\ * corresponding author
}

\section{ARTICLE INFO}

\section{Article history}

Received 2020-05-11

Revised 2020-05-11

Accepted 2020-06-28

\section{Keywords}

Implementation Policy

Work From Home, Welfare

\begin{abstract}
Work from home which is currently being carried out is a follow up to President Joko Widodo's appeal at a press conference at the Presidential Palace, calling for minimization of the spread of the new type of corona virus (SARS-CoV-2) that causes Covid-19, the public is asked to work, study, and worship from home, one of which creates a system of working from home. the purpose of this study was to analyze the Implementation of Work From Home (WFH) Policy on the Welfare of Online Transportation Drivers. The method used in this study uses a litelature study or approach. Data collection in this research was carried out by exploring journals, books and online media. And data processing using Nvivo Plus 12. The results of the study showed that the WFH policy reduced the level of welfare of the online transportation drivers, it can be seen from the level of their needs that were still unfulfilled. Even physiological needs which should be basic needs for everyone, the need for it cannot be fulfilled because their income has decreased dramatically since the enactment of this WFH policy.
\end{abstract}

\section{PENDAHULUAN}

Sejak pertama kali merebak di China pada Desember 2019, virus corona atau yang dikenal dengan istilah Covid 19 dengan cepat terus menyebar hampir di seluruh penjuru dunia. Pada akhir Maret 2020 telah mewabah di lebih 200 Negara di dunia dengan jumlah korban tertular di atas 800 ribu jiwa, lembaga kesehatan dunia WHO pada akhir Januari 2020 awalnya menyatakan Covid-19 sebagai wabah. Namun melihat penularannya yang sangat cepat di seluruh dunia, akhirnya WHO menetapkan Corona Virus sebagai pandemi.

Meski sejak Januari 2020 belahan dunia sudah panik dengan Covid-19, Indonesia baru mengumumkan kasus pertamanya pada 2 Maret 2020 . Presiden Joko Widodo sendiri yang langsung mengumumkan dari istana Negara. Setelah pengumuman itu, hari-hari bangsa ini diisi oleh informasi penambahan pasien positif dan penyebarannya yang begitu cepat di seluruh provinsi di tanah air.

Menyikapi wabah virus Corona atau Covid 19, seluruh lapisan masyarakat saling bekerja sama dalam penanganan Covid-19 dari tingkat pemerintah pusat hingga yang paling bawah ada di lingkup keluarga. Wabah Covid-19 yang lebih viral disebut dengan Wabah Corona membuat dampak sistemik di masyarakat. Sektor pekerjaan baik formal maupun informal seperti pendidikan, pariwisata, perdagangan dan transportasi harus bekerja keras beradaptasi terhadap perkembangan infeksi Covid-19. Berbagai cara pun dilakukan mulai dari dibuatnya kebijakan-kebijakan yang menyangkut mengumpulkan atau berkegiatan dengan orang yang banyak, missal nya penerapan "social distancing" dengan membatasi kunjungan ketempat ramai dan melakukan kontak langsung dengan orang lain. Salah satu metode yang digunakan untuk menerapkan social distancing tersebut adalah dengan bekerja dari rumah atau "Work Form Home" (WFH). Kebijakan ini disambut dengan berbagai reaksi, ada yang menyambut dengan positif dan ada juga yang meragukan apakah WFH bisa diterapkan secara efektif, mengingat penerapannya yang tiba tiba dan kemungkinan kurang siapnya masyarakat akan kebijakan ini dan juga kurangnya fasilitas-fasilitas penunjang lainnya.

Dengan adanya kebijakan Work From Home yang sudah di berlakukan sejak maraknya wabah Corona membuat banyak masyarakat menerima dampaknya, karena tidak semua masyarakat siap 
dengan keadaan seperti ini banyak dari masyarakat yang tidak mempunyai tabungan, perekonomian mereka pun terancam, terutama bagi pekerjaan di bidang transportasi online, Pengemudi sangat mengandalkan menarik penumpang, dengan ada nya kebijakan WFH maka penghasilannya pun menurun drastis, karena sudah jarang sekali orang yang bekerja ke kantor, anak sekolah yang ke sekolah karena sudah diberlakukan nya Work From Home, begitu pun juga dengan proses belajar mengajar mahasiswa yang dilakukan dirumah, maka para pengemudi mengandalkan penghasilan dari transportasi online hanya berharap kepada pengantaran barang ataupun aplikasi pembelian makanan. dan kesejahteraan mereka pun sangat jauh dari kata tercukupi, karena sangat menurunnya penghasilan. Tujuan penelitian ini adalah untuk menganalisis Implementasi Kebijakan Work From Home (WFH) Pada Kesejahteraan Pengemudi Transportasi Online.

Tanggapan Pemerintah Indonesia dalam Pencegahan Bencana COVID-19 oleh Mayusef Sukmana, Muhammad Aminuddin dan Dwi Nopriyanto dalam Jurnal Sarjana Afrika Timur Ilmu Kedokteran Disingkat Judul Utama: Sarjana Afrika Timur J Med Sci ISSN: 2617-4421 (Cetak) \& ISSN: 2617-7188 (Online). WHO telah menetapkan COVID-19 sebagai masalah kesehatan dengan status darurat global dengan tingkat kewaspadaan tertinggi. Indonesia memiliki wilayah yang sangat strategis. Masuk dan keluarnya warga negara Indonesia dan orang asing yang melakukan kegiatan ekonomi, pendidikan, politik, budaya, pariwisata, dan kegiatan lainnya di Indonesia berbahaya bagi penyebaran Covid-19. Indonesia adalah negara dengan dua kasus Covid-19 yang dikonfirmasi. Covid-19 berdampak pada kesehatan, pariwisata, ekonomi, sosial, dan sektor lainnya. Pencegahan penyebaran adalah dengan menanggapi Covid-19 melalui deteksi dini, pengawasan manusia, pengawasan lingkungan, inspeksi peralatan transportasi, dan inspeksi barang.

COVID-19: Dukungan publik untuk menangani dan tantangan ekonomi oleh Mohammad Hidayaturrahman1, Edy Purwanto2. Dalam Jurnal Inovasi dan Economic Vol.5 No.3 Tahun 2020. COVID-19, yang telah menjadi pandemi dunia, telah menghantam sektor ekonomi negara-negara di dunia, termasuk Indonesia. Pertumbuhan ekonomi Indonesia diperkirakan hanya sekitar $2 \%$ atau bahkan $0 \%$. Penelitian ini dilakukan untuk menganalisis bagaimana dukungan publik terhadap upaya pemerintah untuk menangani COVID-19 dan menggambarkan bagaimana tantangan ekonomi yang dihadapi. Penelitian ini menggunakan metode deskriptif kualitatif dengan mengumpulkan data melalui wawancara mendalam dengan beberapa informan yang berkaitan dengan dukungan publik untuk upaya pemerintah. Pengumpulan data juga dilakukan dengan mencari dokumen terkait online. Dari penelitian yang dilakukan, pemerintah memiliki peluang dan kekuatan untuk melakukan inisiatif untuk menghadapi COVID-19. Dukungan administratif, pemerintah daerah, bisnis, partai politik, termasuk oposisi, dan rakyatnya luar biasa. Masalahnya adalah, upaya dan skenario pemerintah tidak terlihat untuk mengantisipasi ancaman ekonomi yang sudah terlihat. Penelitian ini ingin mengungkap kekuatan pemerintah dalam bentuk dukungan publik dalam menangani COVID-19, dan mengingatkan pemerintah, tantangan ekonomi yang dihadapi dengan keberadaan COVID-19.

Dampak Covid-19 terhadap Pendidikan Indonesia dan Kaitannya dengan Filsafat "Merdeka Belajar". Oleh Abidah1. H N Hidaayatullaah2 R M Simamora3. D Fehabutar4. L Mutakinati5. Pandemi Covid - 19 sekarang mulai menyebar ke dunia pendidikan. Kementerian Pendidikan dan Kebudayaan (MOEC) saat ini didasarkan pada informasi resmi, siap dengan semua skenario, termasuk mendorong pembelajaran online untuk siswa. Artikel ini adalah semacam kertas posisi yang membersihkan satu sisi pendapat yang bisa diperdebatkan tentang masalah panas. Tujuan dari makalah posisi adalah untuk meyakinkan pembaca bahwa pendapat kami valid dan dapat dipertahankan. Mengenai posisi kami sebagai peneliti, maka, sudut pandang dipisahkan menjadi empat bagian: Filosofi "Merdeka Belajar", jarak fisik, jarak sosial dan karantina mandiri, pembelajaran digital di Indonesia untuk menghadapi Covid-19, "Merdeka Belajar ', pembelajaran digital, Covid -19, dan pandangan penulis.

\section{LANDASAN TEORI}

\section{Work From Home}

Work From Home adalah suatu istilah bekerja dari jarak jauh, lebih tepatnya bekerja dari rumah, jadi pekerja tidak perlu datang ke kantor tatp muka dengan para pekerja lainnya. Menurut Crosbie \& Moore (2004), bekerja dari rumah berarti pekerjaan berbayar yang dilakukan terutama dari rumah 
(minimal 20 jam perminggu). Bekerja dari rumah akan memberikan waktu yang fleksibel bagi pekerja untuk memberikan keseimbangan hidup bagi karyawan, disisi lain juga memberikan keuntungan bagi perusahaan.

\section{Impelementasi Kebijakan}

Menurut George Edwad III (1980) terdapat 4 faktor yang mempengaruhi keberhasilan atau kegagalan implementasi kebijakan, antara lain yaitu faktor 1). Komunikasi 2). Sumberdaya 3). Disposisi 4). Struktur Birokrasi.

Teori Edwrad III di pilih karena teori ini mudah dipahami dan terperinci serta cocok untuk mengukur sebuah keberhasilan sebuah kebijakan. Implementasi kebijakan secara praktis memerlukan adanya beberapa komponen yang terkait, sehingga menjadikannya lebih terarah. Model implementasi kebijakan public yang dikemukakan oleh Edward III ada empat variable yang berperan penting dalam keberhasilan suatu implementasi kebijakan. Ke empat variable tersebut adalah :

\section{Komunikasi}

Menurut Edward III (1980) komunikasi diartikan sebagai "proses penyampaian informasi komunikator kepada komunikan". Informasi mengenai kebijakan public menurut Edward III perlu disampaikan kepada pelaku kebijakan agar para pelaku kebijakan dapat mengetahui apa yang harus mereka persiapkan dan lakukan untuk menjalankan kebijakan tersebut sehingga tujuan dan sasaran kebijakan dapat dicapai sesuai dengan yang diharapkan.

Menurut Edward III (1980). komunikasi kebijakan memiliki beberapa dimensi, antara lain dimensi transmisi (transmission), kejelasan (clarity), dan konsistensi (consistency).

a) Dimensi transmisi menghendaki agar kebijakan public disampaikan tidak hanya disampaikan kepada pelaksana (implementator) kebijakan, tetapi juga disampaikan kepada kelompok sasaran kebijakan dan pihak lain yang berkepentingan, baik secara langsung maupun tidak langsung.

b) Dimensi kejelasan, menghendaki agar kebijakan yang ditransmisikan kepada pelaksana, target group dan pihak lain yang berkepentingan secara jelas sehingga diantara mereka mengetahui apa yang menjadi maksud, tujuan, sasaran, serta substansi dari kebijakan publik tersebut, sehingga masing-masing akan mengetahui apa yang harus dipersiapkan serta dilaksanakan untuk mensukseskan kebijakan tersebut secara efektif dan efisien.

c) Dimensi konsistensi, diperlukan agar kebijakan yang diambil tidak simpang siur, sehingga membingungkan pelaksana kebijakan, target group dan pihak-pihak yang berkepentingan.

2. Sumberdaya

Edward III (1980) mengemukakan bahwa faktor sumberdaya mempunyai peranan penting dalam implementasi kebijakan. Menurut Edward III (1980) bahwa sumberdaya tersebut meliputi sumberdaya manusia, sumberdaya anggaran, dan sumberdaya peralatan dan sumberdaya kewenangan.

a) Sumberdaya Manusia

b) Sumberdaya Anggaran

c) Sumberdaya Peralatan

d) Sumberdaya Kewenangan

3. Disposisi atau Sikap

Salah satu faktor yang mempengaruhi efektivitas implementasi kebijakan adalah sikap implementor. Jika implemetor setuju dengan bagian-bagian isi dari kebijakan maka mereka akan melaksanakan dengan senang hati tetapi jika pandangan mereka berbeda dengan pembuat kebijakan maka proses implementasi akan mengalami banyak masalah.

Ada tiga bentuk sikap/respon implementor terhadap kebijakan ; kesadaran pelaksana, petunjuk/arahan pelaksana untuk merespon program kearah penerimaan atau penolakan, dan intensitas dari respon tersebut. Para pelaksana mungkin memahami maksud dan sasaran program namun seringkali mengalami kegagalan dalam melaksanakan program secara tepat karena mereka menolak tujuan yang ada didalamnya sehingga secara sembunyi mengalihkan dan menghindari implementasi program. Disamping itu dukungan para pejabat pelaksana sangat dibutuhkan dalam mencapai sasaran program. 


\section{Struktur Birokrasi}

Membahas badan pelaksana suatu kebijakan, tidak dapat dilepaskan dari struktur birokrasi. Struktur birokrasi adalah karakteristik, norma-norma, dan pola-pola hubungan yang terjadi berulang-ulang dalam badan-badan eksekutif yang mempunyai hubungan baik potensial maupun nyata dengan apa yang mereka miliki dalam menjalankan kebijakan.

Pada dasarnya manusia adalah mahluk sosial, baik kita suka atau tidak, hampir semua yang kita lakukan dalam kehidupan kita berkaitan dengan orang lain (Jones, 2009). Kondisi sejahtera (wellbeing) biasanya menunjuk pada istilah kesejahteraan sosial (social welfare) sebagai kondisi terpenuhinya kebutuhan material dan non material. Menurut Midgley (2000: xi) mendefinisiskan kesejahteraan sosial sebagai "..a condition or state of human well-being." Kondisi sejahtera terjadi manakala kehidupan manusia aman dan bahagia karena kebutuhan dasar akan gizi, kesehatan, pendidikan, tempat tinggal, dan pendapatan dapat terpenuhi; serta manakala manusia memperoleh perlindungan dari resiko-resiko utama yang mengancam kehidupannya. Kesejahteraan social di lingkungan masyarakat juga dapat diukur dari segi kebutuhan seperti :

Hierarki Teori Kebutuhan (Hierarchical of Needs Theory)

Menurut Abraham Maslow bahwa pada setiap diri manusia itu terdiri atas lima kebutuhan yaitu Kebutuhan Fisik terdiri dari kebutuhan akan perumahan, makanan, minuman, dan kesehatan. Kebutuhan rasa aman dalam dunia kerja, pegawai menginginkan adanya jaminan sosial tenaga kerja, pensiun, perlengkapan keselamatan kerja, dan kepastian dalam status kepegawaian. Kebutuhan sosial, kebutuhan ini berkaitan dengan menjadi bagian dari orang lain, dicintai orang lain, dan mencintai orang lain. Kebutuhan pengakuan, kebutuhan yang berkaitan tidak hanya menjadi bagian dari orang lain. Sedangkan kebutuhan untuk aktualisasi diri, yaitu kebutuhan untuk menggunakan kemampuan, skill, dan potensi.

Teori Maslow ini masih relevan digunakan walaupun terdapat sebagian kecil orang strata bawah yang menggunakan peralatan modern seperti Handphone Android, namun pemakaian ini karena sebagai alat bekerjanya, seperti pengemudi online (motor maupun mobil) sehingga hal ini tidak menggugurkan Teori Maslow. Secara umum Teori Maslow tetap berlaku.

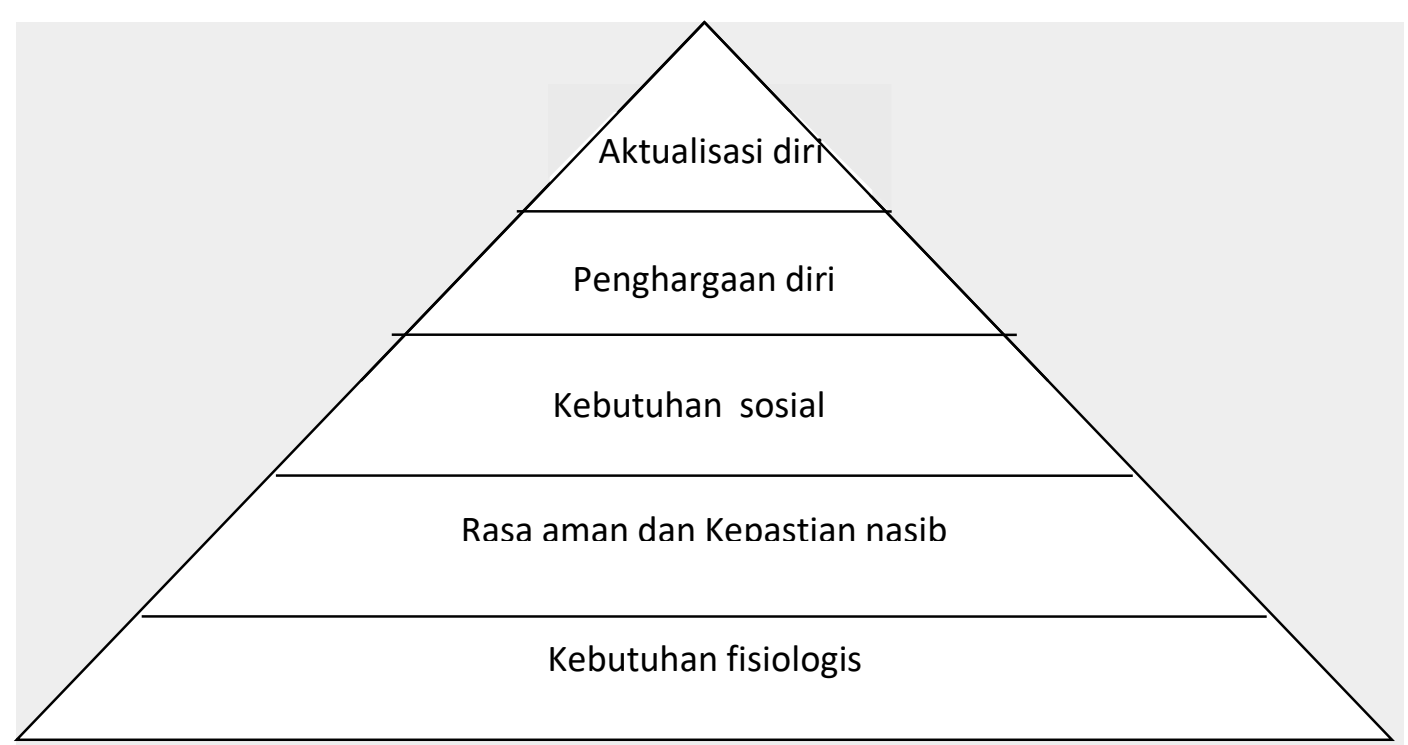

Gambar 1. Hierarki Kebutuhan Maslow

Semakin ke atas kebutuhan seseorang semakin sedikit jumlah atau kuantitas manusia yang memiliki kriteria kebutuhannya.

1. Kebutuhan Fisiologis 
pada tingkat yang paling bawah, terdapat kebutuhan yang bersifat fisiologis (kebutuhan akan udara, makanan, minuman dan sebagainya) yang ditandai oleh kekurangan (defisit) sesuatu dalam tubuh orang bersangkutan. Kebutuhan ini dinamakan juga kebutuhan dasar.

2. Kebutuhan Rasa Aman

Jenis kebutuhan ini berhubungan dengan jaminan kemanan, stabilitas, perlindungan, struktur, keteraturan, situasi yang bisa diperkirakan, bebas dari rasa takut, cemas dan sebagainya.

3. Kepemilikan Sosual/Kebutuhan Sosial

Setelah kebutuhan dasar dan rasa aman relatif dipenuhi, maka timbul kebutuhan untuk dimiliki dan dicintai.

4. Kebutuhan Harga Diri

Disisi lain, jika kebutuhan tingkat tiga relatif sudah terpenuhi maka timbul kebutuhan akan harga diri. Ada dua macam kebutuhan akan harga diri, pertama adalah kebutuhan akan kekuatan, penguasaan, kompetensi dan percaya diri. Yang kedua adalah kebutuhan atas penghargaan diri dari orang lain.

5. Kebutuhan Aktualisasi Diri

Kebutuhan aktualisasi diri merupakan kebutuhan yang terdapat 17 meta kebutuhan yang tidak tersusun secara hierarki, melainkan saling mengisi.

\section{METODE}

Metode yang digunakan dalam penelitian ini menggunakan metode Studi Literatur dengan pendekatan Kualitatif. Metode Studi Litelature ini dipilih untuk menyesuaikan situasi dan kondisi yang sedang terjadi di dunia termasuk Indonesia, yaitu adanya pandemic Covid-19. Sehingga peneliti tidak dapat melakukan wawancara dan observasi ke lapangan, karena dapat membahayakan diri peneliti maupun informan bila terserang wabah Covid-19 tersebut. Peneliti menulusuri informasi dari media massa online, yaitu : Detik.com, Kompas.com dan Republika.com setelah itu informasi dari sumber berita media massa online diolah menggunakan aplikasi Nvivo.

NVivo adalah paket perangkat lunak komputer analisis data kualitatif (QDA) yang diproduksi oleh QSR International . NVivo membantu peneliti kualitatif untuk mengatur, menganalisis, dan menemukan wawasan dalam data tidak terstruktur atau kualitatif seperti wawancara, respons survei terbuka, artikel jurnal, media sosial, dan konten web, di mana diperlukan tingkat analisis mendalam pada volume data yang kecil atau besar. Data yang didapat dicoding dengan mengklarifikasikan dalam kelompok indikator dalam Teori Edward III dan dalam teori Maslow, setelah dicoding maka dilakukan Crosstab dan Cluster Analysis berupa tabel yang menunjukkan angka persenan.

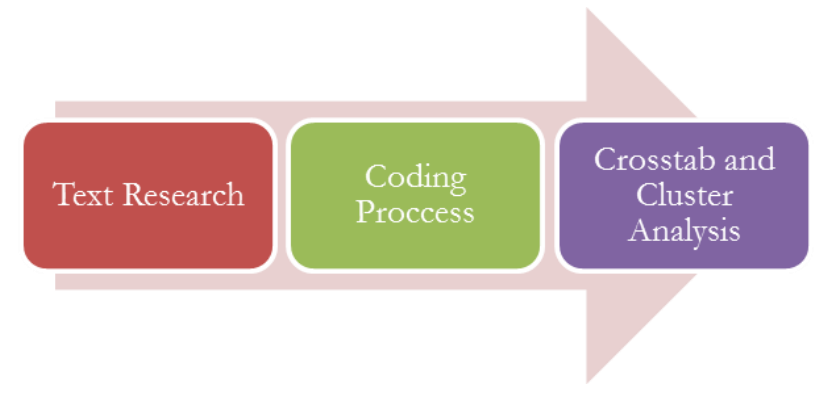

Gambar 2. Conceptual Framework

Text research, mencari dan mengumpulkan data dari pemberitaan online tentang kebijakan Work From Home, kemudian data tersebut diolah dengan mengkodingnya, yaitu pengolahan data dengan memasukan setiap kalimat ke dalam cluster-clusternya, setelah dilakukan coding maka data tersebut akan menghasilkan tabel yang berupa angka atau persenan yang disebut juga Crosstab dan Cluster Analysis. 


\section{HASIL DAN PEMBAHASAN}

Dari data yang telah diolah dari 3 sumber berita yang berbeda yaitu Kompas Online, Detik Online dan Republika Online dalam implementasi kebijakan WFH pada kesejahteraan pengemudi transportasi online, yang terkait variable komunikasi Eduard III hasilnya sebagai berikut :

\section{Komunikasi}

Komunikasi yang merupakan salah satu unsur penting yang mempengaruhi implementasi kebijakan, karena komunikasi sangat menentukan keberhasilan pencapaian tujuan dari implementasi kebijakan itu sendiri. Terdapat tiga indikator yang digunakan dalam mengukur keberhasilan komunikasi, yaitu : Transmisi, Kejelasan dan Konsistensi.

Tabel 1. Komunikasi

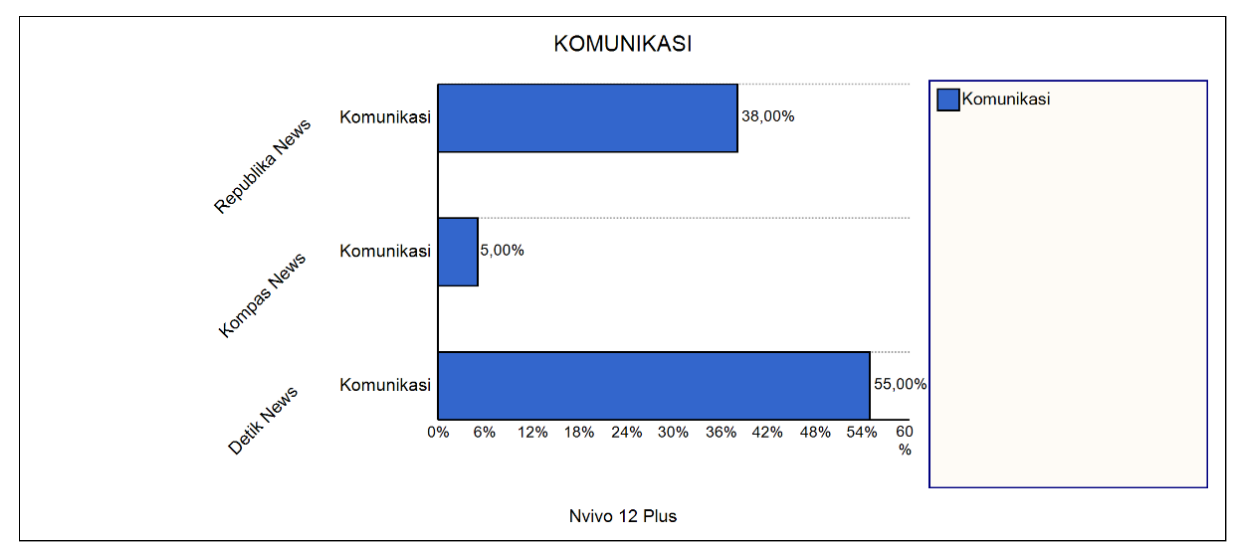

Berdasarkan data yang telah diolah di atas dapat dilihat bahwa pemberitaan dalam konteks Komunikasi di pemberitaan Detik.com sebanyak 55\% disusul oleh Republika.com sebanyak 38\% sedangkan dalam Kompas.com hanya sebanyak 5\%.

Transmisi atau penyaluran komunikasi yang dilakukan pemerintah tidak 2 arah, karena pemerintah hanya menyampaikan kebijakan Work From Home lewat media massa, tidak ada nya himbauan dari pemerintah untuk menerapkan kebijakan WFH secara komunikasi dua arah dengan masyarakat.

Kejelasan komunikasi yang disampaikan pemerintah juga sudah cukup jelas, sering sekali pemerintah mengingatkan kepada masyarakat akan pentingnya Work From Home, mulai dari pemberitaan sampai ke semua lini media massa bahwa pemerintah membuat kebijakan Work From Home untuk memutus mata rantai penyebaran Covid -19 di Indonesia.

Konsistensi, dalam hal ini pemerintah terus mengingatkan bagi seleruh perusahaan untuk dapat menerapkan Work From Home, konsistensi pemerintah dalam kebijakan WFH juga sangat jelas dengan melibatkan pemerintah daerah untuk dapat memberikan sanksi tegas kepada perusahaan yang masih tidak menerapkan WFH.

Komunikasi yang disampaikan pemerintah kepada masyarakat akan kebijakan Work From Home , seperti dalam kutipan ini "Semenjak adanya kasus positif corona di Indonesia, imbauan kerja dari rumah atau Work From Home terus digaungkan pemerintah. Banyak pekerja dari berbagai sektor sudah menerapkan himbauan itu". (Detik.com) 
Tabel 2. Struktur Komunikasi

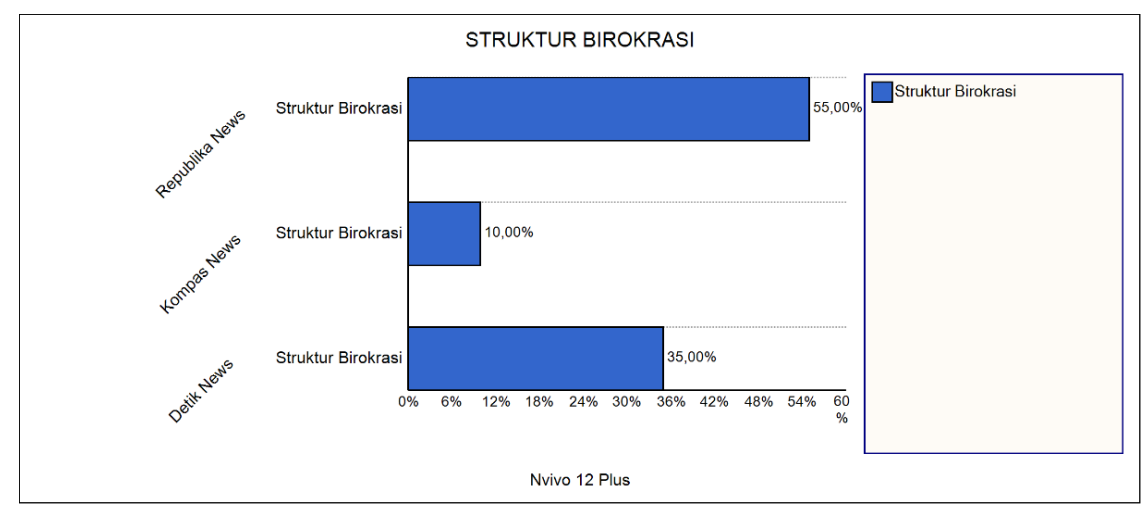

Struktur bokrasi membahas badan pelaksana suatu kebijakan, tidak dapat dilepaskan dari struktur birokrasi. Struktur birokrasi adalah karakteristik, norma-norma, dan pola-pola hubungan yang terjadi berulang-ulang dalam badan-badan eksekutif yang mempunyai hubungan baik potensial maupun nyata dengan apa yang mereka miliki dalam menjalankan kebijakan. yang merupakan salah satu faktor yang fundamental dalam mengkaji sebuah implementasi kebijakan dalam hal ini menunjukan bahwa dalam pemberitaan di Republika News menempati peringkat pertama, masih terjadinya tumpang tindih kebijakan yang dibuat oleh Pemerintah maupun oleh Pememerintah Daerah yang tidak sejalan dengan Kebijakan Pemerintah pusat, seperti hal nya Permenhub No 18 Tahun 2020 tentang Pengendalian Transportasi Dalam Rangka Pencegahan Penyebaran Covid-19 dan Permenkes No 9 Tahun 2020 didahulukan dibandingkan Permenhub tersebut. Permenhub tersebut diatur tentang pengoperasian kendaraan umum termasuk angkutan ojek online (ojol). "Pada Pasal 11 ayat 1 huruf c ditegaskan bahwa ojol hanya dapat melakukan kegiatan pengantaran barang, namun pada huruf d diberikan pengecualian, bahwa dalam hal tertentu untuk tujuan melayani kepentingan masyarakat dan untuk kepentingan pribadi, sepeda motor dapat mengangkut penumpang dengan ketentuan harus memenuhi protokol kesehatan." Tidak sejalan dengan Permenkes No 9 Tahun 2020 tentang Pedoman Pembatasan Sosial Berskala Besar (PSBB) dalam Rangka Percepatan Penanganan Covid-19. "Pada Pasal 13 ayat 10 disebutkan bahwa moda transportasi baik umum maupun pribadi dibatasi dengan memperhatikan jumlah penumpang dan menjaga jarak antar penumpang,"seperti hal dalam kutipan ini "Yang mengizinkan (ojek online beroperasi) siapa? ya sudah tanya Kementerian Perhubungan (Kemenhub) saja kenapa mengizinkan. Karena sudah ada aturannya, kamu baca saja," ujar Direktur Jenderal (Dirjen) Pencegahan dan Pengendalian Penyakit (P2P) Kemenkes Achmad Yurianto saat dihubungi Republika.co.id, Senin (13/4).

Ia juga menyebut pemerintah daerah (pemda) juga memiliki peraturan daerah mengenai hal ini. Dia menambahkan, petunjuk pelaksanaannya ada di tangan Pemda. "Kemenhub memang terserah membuat aturan, tetapi masyarakat juga menjalankan aturan yang dibuat Pemda. Pemdanya mengizinkan atau tidak, karena bukan pemerintah pusat yang mengatur hal-hal kecil seperti itu," katanya.. Hal ini membuat struktur birokrasi dalam implementasi kebijakan WFH belum berjalan dengan baik.

Tabel 3. Disposisi

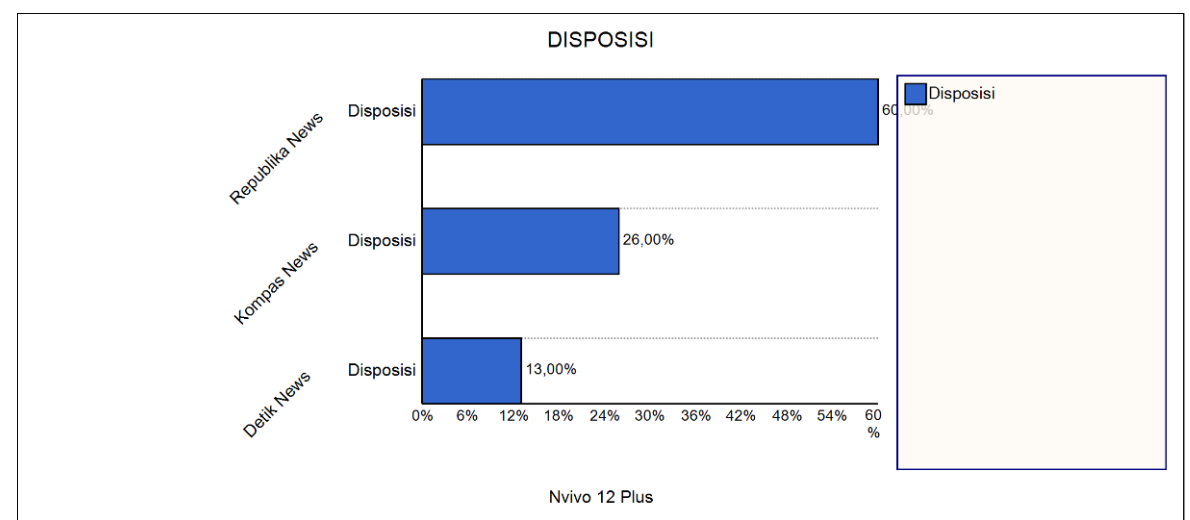


Disposisi menurut Edward III lebih banyak diberitakan dalam Republika News yaitu sebanyak 60\% disusul oleh Kompas News sebanyak 26\% dan Detik News 13\%. Pemberitaan Disposisi ini Ada tiga bentuk sikap/respon implementor terhadap kebijakan ; kesadaran pelaksana, petunjuk/arahan pelaksana untuk merespon program kearah penerimaan atau penolakan, dan intensitas dari respon tersebut. Para pelaksana mungkin memahami maksud dan sasaran program namun seringkali mengalami kegagalan dalam melaksanakan program secara tepat karena mereka menolak tujuan yang ada didalamnya sehingga secara sembunyi mengalihkan dan menghindari implementasi program. kebijakan Work From Home yang diambil oleh pemerintah yang dimana hambatan hambatan yang dialami adalah ketidaksinambungan kebijakan yang dibuat oleh pemerintah. "Ditengah-tengah maraknya kasus pandemi Covid-19 yang sangat berpengaruh besar bagi segala aspek didalam masyarakat khususnya pada aspek ekonomi dan kesejahteraan social. Bukan hanya merebak dan membesarnya daerah persebaran Covid-19 saja namun juga tentang tidak seimbangnya kebijakan pembatasan, isolasi, hingga pelarangan aktivitas di luar rumah terhadap rakyatnya. Sehingga menimbulkan perekonomian dunia dikarenakan Covid-19 dan pelarangan aktivitas di luar rumah sehingga inflasi didalam rumah tangga masyarakat pun tidak dapat terhindarkan. Jadi karena itulah ketidakseimbangan terjadi antara ekonomi dan kebijakan. (Indonesiana.id).

Tabel 4. Sumber Daya

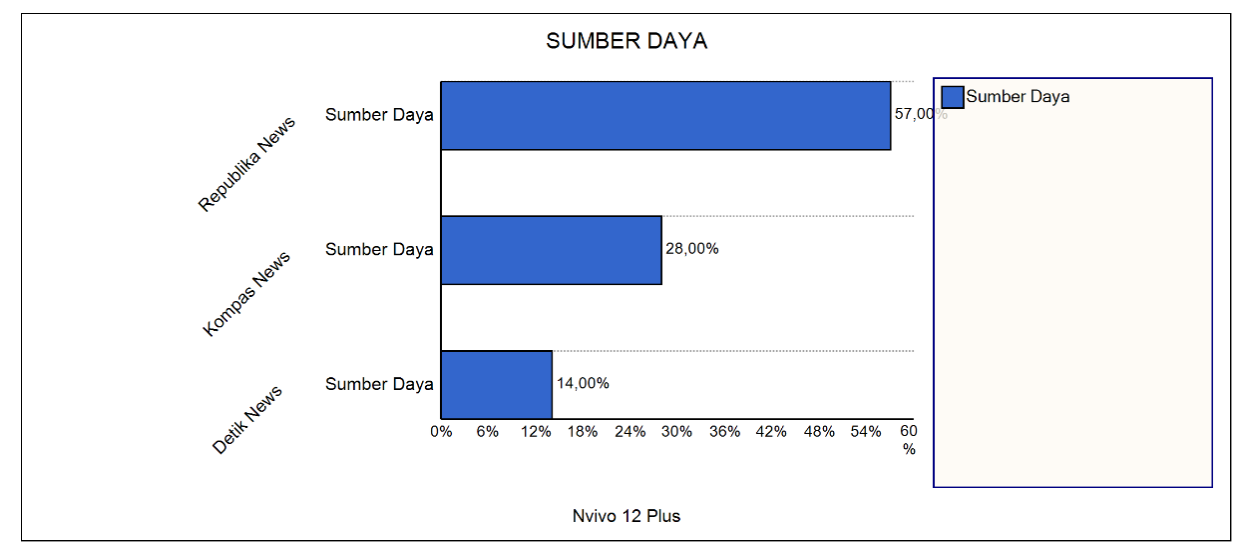

Dalam Variabel Sumber Daya Republika News menempati tingkat tertinggi dalam pemberitaan sumber daya pemerintah dalam menangani Covid 19, dalam Republika News sebanyak 57\% kemudian Kompas News sebanyak 28\% dan yang terakhir Detik News sebanyak $14 \%$. Hal ini di tunjukan dengan banyaknya pemberitaan yang dipublish oleh Republika News bagaimana pemerintah memiliki sumber daya dalam penanganan Covid 19 mulai dari sumber daya manusia, sumber daya dana , fasilitas dan wewenang. Dalam indikator sumber daya pemerintah menggandeng kepolisian dan dinas perhubungan untuk menerapkan kebijakan WFH, pemerintah daerah juga selalu mengingatkan kepada para perusahaan untuk dapat melaksanakan kebijakan WFH ini, dan memberikan tindakan tegas bagi yang melanggar, selain itu pemerintah pusat dan daerah juga saling memberikan bantuan untuk masyarakat yang terkena dampak kebijakan WFH dan Covid-19.

Pemerintah memiliki wewenang dalam membuat suatu kebijakan, yang dimana kebijakan ini adalah kebijakan untuk Work From Home, yang bertujuan untuk dapat mengurangi aktivitas ataupun mobilitas masyarakat di luar rumah untuk memutus mata rantai penyebaran Covid-19.

Selanjutnya, untuk Teori Maslow dengan 5 tingkat secara hierarchi dideskripsikan hasil penelitiannya sebagai berikut : 
Tabel 3. Fisiologis

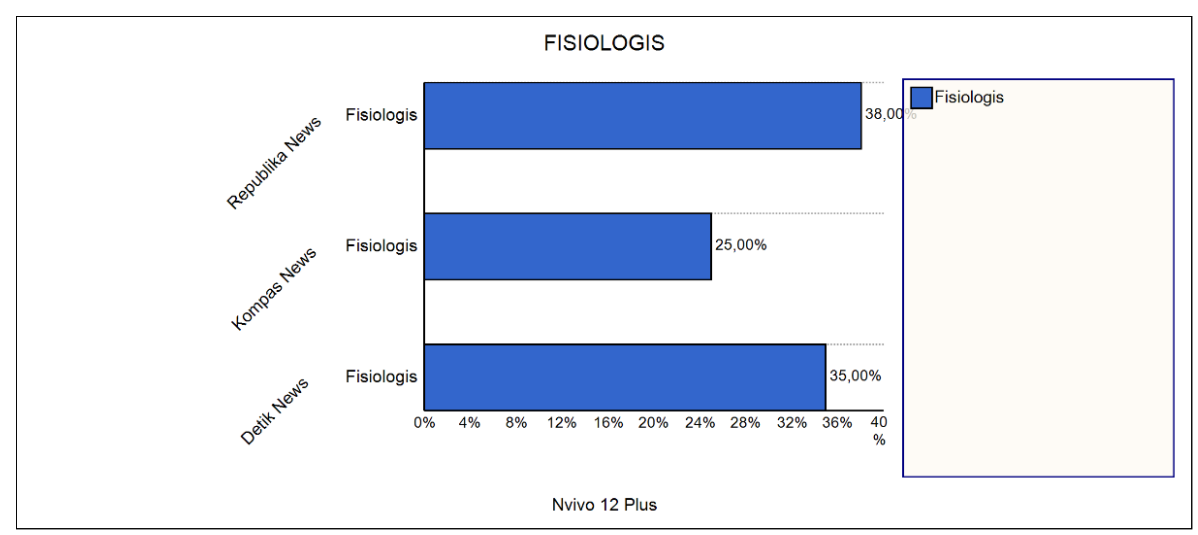

Kebutuhan Fisiologis merupakan kebutuhan yang paling mendasar, dalam hal ini kebutuhan fisiologis para pengemudi transportasi online yang terkena dampak dari kebijalan Work From Home menurut Republika News sebanyak 38\% sedangkan Detik News sebanyak 35\% dan Kompas News 25\%. Kebijakan WFH yang diambil oleh pemerintah akhirnya juga membuat perusahaan menerapkan kebijakan tersebut maka dari itu pendapatan transportasi online pun menjadi menurun, dengan adanya kebijakan WFH pun pengemudi banyak yang merasakan penurunan pendapatan, hingga mereka bingung bagaima memenuhi kebutuhan dasar mereka, bahkan hingga $65 \%$ dengan begitu penghasilan pengemudi pun menjadi sangat turun. Menurut lembaga Statqo Analytics yang mengkaji kondisi dua perusahaan transportasi online yaitu Grab dan Gojek, pengguna aktif transportasi online mengalami penurunan sejak pertengahan Maret 2020 lalu. Tepatnya setelah pemberlakuan imbauan work from home (WFH) sebagai upaya mencegah penyebaran virus corona.

"Secara signifikan itu mulai menurun sejak diberlakukannya kebijakan WFH dan mulai meliburkan sekolah sejak minggu kedua Maret 2020," ujar Marketing and Creative Content Statqo Adzkia Arif kepada detikcom, Selasa (31/3/2020). (Detik.com). Dengan penghasilan yang sedikit, pengemudi pun mengeluh tidak dapat memenuhi kebutuhan di rumah yang menjadi kebutuhan dasar atau kebutuhan fisik minimal, bahkan ada pengemudi transportasi online yang diusir dari kontrakan karena tidak dapat membayar sewa kontrakan yang dapat dilihat dalam kutipan ini "pengemudi ojek online yang sempat diusir dari kontrakan akibat tak mampu membayar sewa". (Kompas.com).

Tabel 4. Rasa Aman

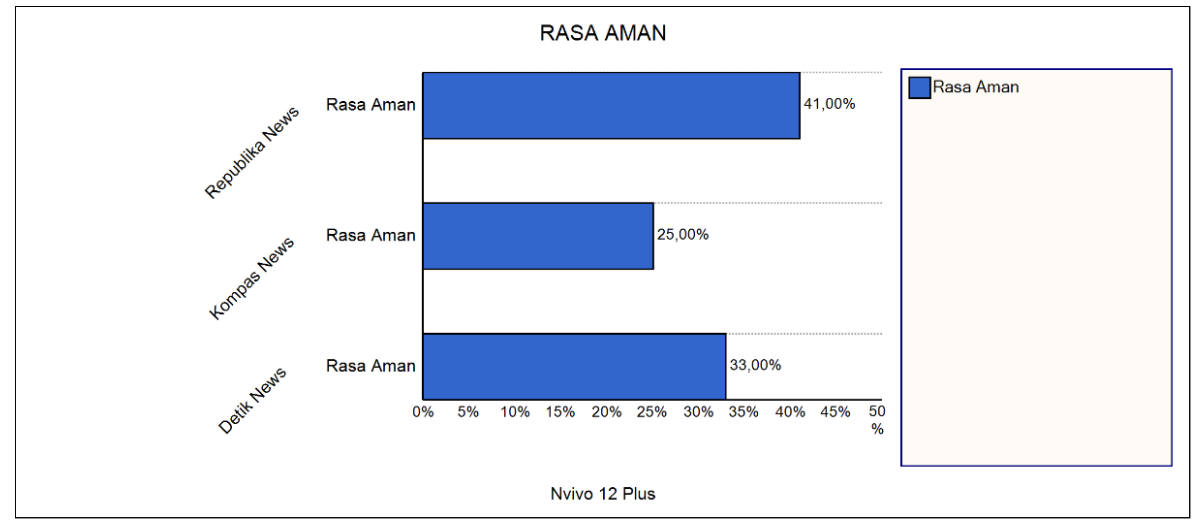

Selanjutnya adalah Kebutuhan Rasa Aman, dalam hal ini setiap manusia juga membutuhkan jaminan keamanan, stabilitas . dengan adanya kebijakan WFH memang dikeluarkan oleh pemerintah untuk melindungi warganya agar tidak terjangkit virus, tetapi apakah dengan membuat kebijakan WFH dapat menjamin stabilitas perekonomian masyarakat, terlebih lagi para pengemudi transportasi online yang notabene mengandalkan jasa pengantaran. Seperti dalam kutipan ini "Saat ini kami sebagai pengemudi taksi online sedang sedih sekali. Dari tanggal 20 Maret kemarin, para pengemudi sudah 
mulai merasakan dampak corona, sudah tak ada penumpang karena semua sekolahan kan pada tutup, yang kuliah dan yang kerja juga begitu," ujar Tabrani kepada detikcom, Senin (30/3/2020).

Biasanya Tabrani mampu mengumpulkan pendapatan hingga Rp 1,3 juta per minggunya. Namun, sejak tanggal 23 Maret 2020 lalu, pendapatannya mentok di angka Rp 60.000-70.000 saja. Bahkan, hari ini Tabrani mengaku tak memperoleh satupun orderan penumpang. (Detik.com).

Tabel 5. Kepemilikan Sosial

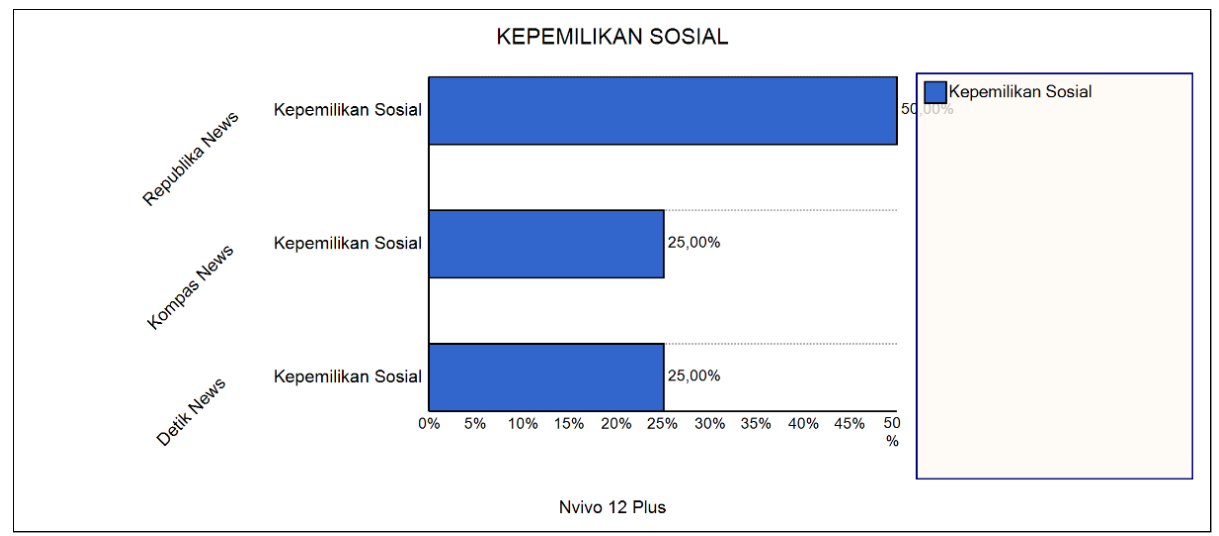

Dalam hal ini Kepemilikan Sosial yang ingin diperhatikan sebagai masyarakat yang terkena dampak kebijakan WFH yang telah dikeluarkan oleh pemerintah. Dari pemberitaan di Republika News paling banyak dengan angka 50\% dalam kepemilikan sosial yang dibahas, yaitu dengan bagaimana pemerintah membuat para pengemudi transportasi online memerlukan perhatian pemerintah, maka pemerintah membuat sedikit keringanan untuk para transportasi online "Sebelumnya, Presiden Joko Widodo telah menjanjikan kelonggaran atau relaksasi kredit kepada pelaku usaha mikro dan kecil yang penghasilannya terdampak wabah Covid-19.

Termasuk di dalamnya keringanan untuk membayar cicilan kendaraan bermotor. Relaksasi atau kelonggaran kredit ini diatur dalam POJK No. 11/POJK.03/2020 yang berlaku sejak 16 Maret 2020 hingga 31 Maret 2021. (Kumparan.com).

Tabel 6. Penghargaan Diri

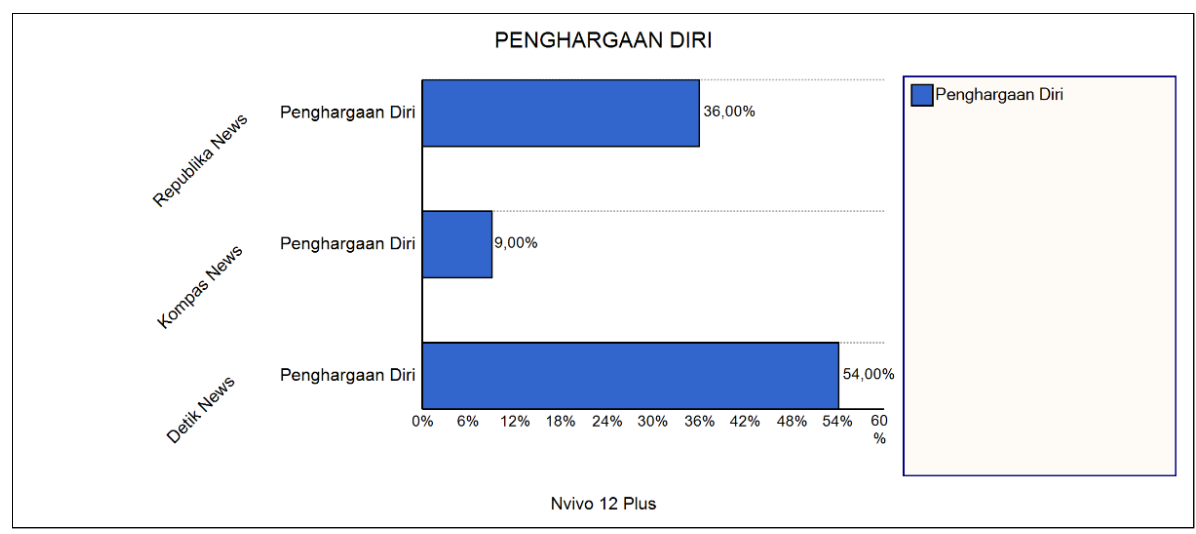

Kebutuhan Penghargaan diri terbanyak dibahas oleh Detik news sebanyak 54\% dalam kebijakan Work From Home harusnya pemerintah dapat memberikan kesejahteraan kepada para pengemudi transportasi online tetapi dengan adanya kebijakan Work From Home membuat para pengemudi transportasi online menjadi khawatir dan takut akan kesejahteraan hidup mereka, semenjak diberlakukan nya Work From Home dan menurunnya pendapatan para pengemudi transportasi online banyak yang tidak dapat memenuhi kehidupannya, apalagi ada yang sampai tidak dapat membayar kontrakan dan sampai diusir dari kontrakan tersebut, maka dengan ini para pengemudi membutuhkan bantuan dan apresiasi dari pemerintah dan bahkan membuat para pengemudi menjadi tergantung akan bantuan dari orang lain. 
Tabel 7. Aktualisasi Diri

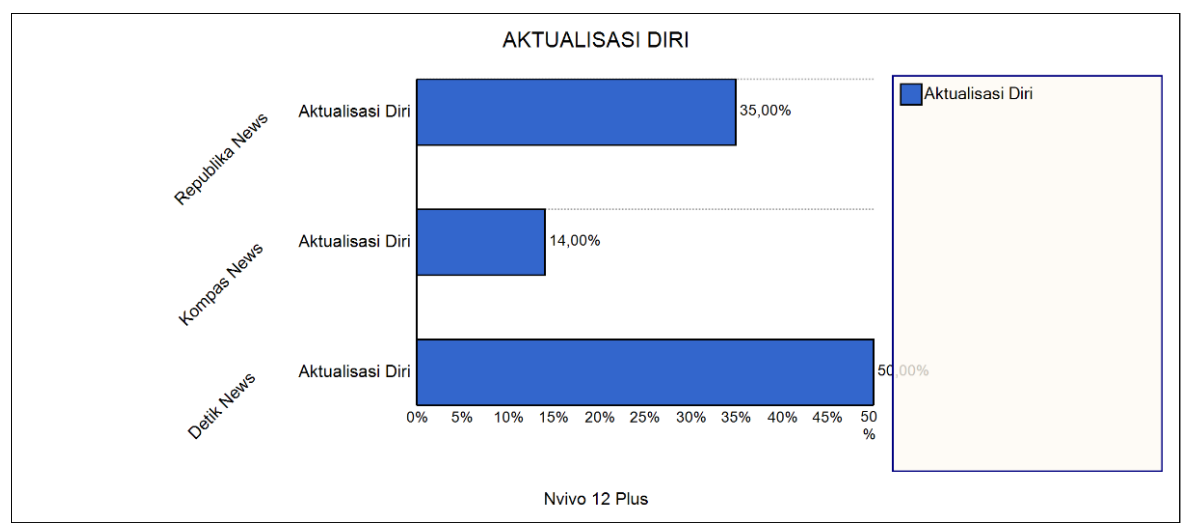

Aktualisasi Diri yaitu keinginan seseorang untuk menggunakan semua kemampuan dirinya untuk mencapai apapun yang mereka mau dan bisa dilakukan. Ahli jiwa Abraham Maslow, dalam bukunya Hierarchy of Needs menggunakan istilah aktualisasi diri sebagai kebutuhan dan pencapaian tertinggi seorang manusia.

Berdasarkan tabel di atas dapat diketahui bahwa pemberitaan di Detik.com dalam konteks Aktualisasi Diri sebanyak 50\%, sedangkan Republika.com sebanyak 35\% dan Kompas.com hanya sebesar $14 \%$. Pemenuhan asktualisasi diri belum dapat terpenuhi dikarenakan semua masih ada di tangan pemerintah yang membuat kebijakan dan para transportasi online pun harus mematuhi segala keputusan yang dibuat oleh pemerintah. Para pengemudi transportasi online pun membutuhkan kerjasama antara pemerintah dan pengolah aplikasi transportasi online untuk dapat mengatasi permasalahan ekonomi dalam kebijakan Work From Home.

\section{KESIMPULAN DAN SARAN}

Untuk menganalisis Implementasi Kebijakan Work From Home (WFH) Pada Kesejahteraan Pengemudi Transportasi Online.

Implementasi Kebijakan Work From Home menimbulkan akibat turunnya kesejahteraan para pengemudi Transportasi Online, karena sebagian besar orang tinggal di rumah. Di bidang Kesehatan kebijakan WFH untuk mengurangi penularan covid 19 tetapi di bidang ekonomi, pendapatan masyarakat turun drastis. Namun kedua bidang tersebut tidak layak untuk dianggap sebagai dikotomi/berdiri berhadapan. Akibat tersebut secara alamiah selalu terjadi.

\section{Saran}

Berdasarkan kesimpulan di atas, perlu dilakukan beberapa hal, yaitu :

1. Diperlukan Kebijakan baru sebagai Penyelaras Kebijakan WFH yaitu Kebijakan Tenttang Pengembangan Ekonomi Rakyat.

2. Perlunya Peningkatan kerjasama antara pemerintah dengan swasta.

\section{DAFTAR PUSTAKA}

Juanedi, Fajar. 2020. Krisis Komunikasi dalam Pandemi Covid-19. Buku Litera, Yogyakarta.

Mayusef Sukmana ${ }^{1}$, Muhammad Aminuddin ${ }^{1}$, Dwi Nopriyanto ${ }^{1}$. 2020. Tanggapan Pemerintah Indonesia dalam Pencegahan Bencana COVID-19. East African Scholars Journal of Medical Sciences. Vol. 3 No.3 Tahun 2020.

Mohammad Hidayaturrahman ${ }^{1}$, Edy Purwanto' ${ }^{2}$ 2020. COVID-19: Dukungan publik untuk menangani dan tantangan ekonomi. Jurnal Inovasi dan Ekonomi. Vol. 5 No.3 Tahun 2020.

A Abidah ${ }^{1}, \mathrm{H}$ N Hidaayatullaah ${ }^{2}$, R M Simamora ${ }^{3}$, D Fehabutar ${ }^{4}$, L Mutakinati $^{5}$. 2020. Dampak Covid-19 terhadap Pendidikan Indonesia dan Kaitannya dengan Filsafat "Merdeka Belajar". Studies in Philosophy of Science and Education (SiPoSE). Vol.1 No.1 Tahun 2020. 
Edward, George. C.1980. Implementing Public Policy. Washington D.C: Congressional Quarterly Inc.

Jones, Pip. 2009. Pengantar Teori-Teori Sosial. Jakarta : Yayasan Obor Indonesia.

Midgley, J. 2000. Globalization, Capitalism and Sosial Welfare: A Sosial Development Perspective. Canadian Sosial Work, Special Issue: Sosial Work and Globalization, 2(1):13-28.

Abraham H. Maslow, 2010, Motivation and Personality. Rajawali, Jakarta.

Sumber Lain:

Rangga Rahadiansyah. 2020. Banyak Karyawan 'Work From Home', Orderan Ojek Online Anjlok. https://oto.detik.com/motor/d-4943927/banyak-karyawan-work-from-home-orderan-ojek-onlineanjlok. di akses pada 7 April 2020 Pukul 12:26 WIB.

Soraya Novika. 2020. Banyak yang Kerja dari Rumah, Driver Online Kena Apesnya. https://finance.detik.com/berita-ekonomi-bisnis/d-4958477/banyak-yang-kerja-dari-rumahdriver-online-kena-apesnya. di akses pada 7 April 2020 Pukul 12:08 WIB.

Soraya Novika. 2020. Bisnis Transportasi Online Kena Imbas Corona, Ini Datanya. https://finance.detik.com/berita-ekonomi-bisnis/d-4959541/bisnis-transportasi-online-kenaimbas-corona-ini-datanya. di akses pada 7 April 2020 Pukul 12:06 WIB.

Herdi Alif Al Hikam. 2020. Driver Online Curhat, Leasing Tolak 'Libur' Cicilan Kredit. https://finance.detik.com/moneter/d-4954659/driver-online-curhat-leasing-tolak-libur-cicilankredit/3. di akses pada 7 April 2020 Pukul 12:12 WIB.

Sylke Febrina Laucereno. 2020. Dengar Ratapan Driver Ojol di Kala PSBB: Diusir dari Kontrakan!. https://finance.detik.com/berita-ekonomi-bisnis/d-4972690/dengar-ratapan-driver-ojol-di-kalapsbb-diusir-dari-kontrakan?_ga=2.36042976.1992471222.15869548131527548813.1532169557. di akses pada 16 April 2020 Pukul 10:02 WIB.

Rangga Rahadiansyah. 2020. Jangan Lockdown, Ojol Butuh Pendapatan buat Nafkah dan Cicilan Motor. https://oto.detik.com/motor/d-4943723/jangan-lockdown-ojol-butuh-pendapatan-buat-nafkahdan-cicilan-motor. di akses pada 8 April 2020 Pukul 11:41 WIB.

Kurniasih Budi. 2020. "Covid-19 Intai Kesejahteraan Masyarakat Miskin dan Rentan Miskin, Irwan Hidayat Turun Tangan Bagikan Paket Bahan Pokok", https://money.kompas.com/read/2020/03/24/000634226/covid-19-intai-kesejahteraanmasyarakat-miskin-dan-rentan-miskin-irwan-hidayat. di akses pada 14 April 2020 Pukul 17:57 WIB.

Vitorio Mantalean. 2020. "Dodo, Pengemudi Ojek Online yang Diusir dari Kontrakan, Terima Donasi Sembako dari Pembaca Kompas.com", https://megapolitan.kompas.com/read/2020/04/11/12074311/dodo-pengemudi-ojek-online-yangdiusir-dari-kontrakan-terima-donasi. di akses pada 14 April 2020 Pukul 16:57 WIB.

Michael Hangga Wismabrata. 2020. "Kisah Haru Driver Ojol di Tengah Wabah Corona, Sepi Order hingga Dapat Makan Gratis", https://yogyakarta.kompas.com/read/2020/03/27/05300081/kisahharu-driver-ojol-di-tengah-wabah-corona-sepi-order-hingga-dapat-makan?page=all di akses pada 13 April 2020 Pukul 13:25 WIB.

Gilang Satriya. 2020. "Pekan Pertama WFH Penghasilan Ojol Turun Drastis", https:/otomotif.kompas.com/read/2020/03/24/115254015/pekan-pertama-wfh-penghasilan-ojolturun-drastis di akses pada 13 April 2020 Pukul 13:36 WIB.

Mutia Fauzia. 2020. "Selain Masyarakat Miskin, BLT Dialokasikan untuk Driver Ojol dan Pegawai Mal", https://money.kompas.com/read/2020/03/26/121034426/selain-masyarakat-miskin-bltdialokasikan-untuk-driver-ojol-dan-pegawai-mal di akses pada 13 April 2020 Pukul 13:29 WIB.

Tantri Dewayani. 2020. Bekerja dari Rumah (Work From Home) Dari Sudut Pandang Unit Kepatuhan Internal. https://www.djkn.kemenkeu.go.id/artikel/baca/13014/Bekerja-dari-Rumah-Work-FromHome-Dari-Sudut-Pandang-Unit-Kepatuhan-Internal.html di akses pada 7 April 2020 Pukul 11:39 WIB. 
Hiru Muhammad. 2020. Gojek Luncurkan 12 Program Kesejahteraan Mitra Driver. https://republika.co.id/berita/q8350s380/gojek-luncurkan-12-program-kesejahteraan-mitra-driver di akses pada 14 April 2020 Pukul 17:42 WIB.

Neil E. Prayoga. 2020. Implementasi Work From Home Sebagai Upaya "Social Distancing": A Blessing in Disguise? https://www.djkn.kemenkeu.go.id/artikel/baca/13010/Implementasi-Work-FromHome-Sebagai-Upaya-Social-Distancing-A-Blessing-in-Disguise.html di akses pada 7 April 2020 Pukul 11:40 WIB.

Sapto Andika Candra. 2020. Permenhub Izinkan Ojol Bawa Penumpang Hingga Bansos Turun. https://republika.co.id/berita/nasional/umum/q8pw5w382/permenhub-izinkan-ojol-bawapenumpang-hingga-bansos-turun di akses pada 14 April 2020 Pukul 17:23 WIB.

Bayu Hermawan. 2020. PSBB, Legislator: Permenhub Soal Transportasi Jangan Ambigu https://republika.co.id/berita/nasional/umum/q8pxu7354/psbb-legislator-permenhub-soaltransportasi-jangan-ambigu di akses pada 14 April 2020 Pukul 17:18 WIB.

Muhammad Akbar. 2020. Pengamat: Transportasi Harus Tunduk pada Peraturan PSBB https://republika.co.id/berita/q8q8k9480/pengamat-transportasi-harus-tunduk-pada-peraturanpsbb di akses pada 14 April 2020 Pukul 17:36 WIB.

Reiny Dwinanda. 2020. WHO: Negara Harus Jamin Martabat, Kesejahteraan Rakyat https://republika.co.id/berita/q82ekq414/who-negara-harus-jamin-martabat-kesejahteraan-rakyat di akses pada 14 April 2020 Pukul 17:48 WIB.

Arbie, Naefael, 2020. Corona, Karantina, dan Ekonomi Kita. https://www.indonesiana.id/read/139534/corona-karantina-dan-ekonomi-kita diakses pada $26 \mathrm{Mei}$ 2020 Pukul 21:12 WIB.

Sukmawijaya, Angga. 2020. Ojol curhat susah dapat keringanan cicilan motor, ini jawaban Bank dan OJK. https://kumparan.com/kumparanbisnis/ojol-curhat-susah-dapat-keringanan-cicilan-motorini-jawaban-bank-dan-ojk-1tBfovVo7FM/full diakses pada 26 Mei 2020 Pukul 21:32 WIB. 